\title{
Dependence between infiltration capacity and karst processes in river catchments
}

\author{
Zinoviy Iofin* \\ Vologda State University, Lenina 15, 160000, Vologda, Russia
}

\begin{abstract}
The article shows the empirical dependence between the cavern volume filled with water and infiltration capacity. This dependence makes it possible to estimate how karst influences infiltration capacity and run-off and water balance as well.
\end{abstract}

\section{Introduction}

The main problem in studying karst influence on hydrological parameters is heterogeneity of karst areas.

Many scientists investigated how karst influences run-off. The work [1] is based on studying karst influence on minimum run-off. Increasing or decreasing minimum run-off in karst rivers in comparison with the rivers without karst is a consequence of karst influence on run-off. The work [2] made a significant contribution to karst studies suggesting and defining four main eras of reservoir rock development throughout the hydrogeological history of Earth: fractured, pored, karstic and anthropogenic. Many Cuban scientists investigate the problems of karst: [3], [4] and others.

\section{Materials and methods}

Observation data from the Cuban rivers, especially from western regions where karst is widely spread, are used to study how karst changes river run-off. There is karst in eastern Cuban regions too but it is considered to be covered (i.e. karsting rocks are covered by comminute insoluble precipitate on the surface).

\section{Karst types description}

The study describes western Cuba areas presented in Fig. 1. The description is based on [4] where the author distinguishes five karst areas.

The material of the study is annual average streamflow of the rivers in eastern and western Cuba: 21 water stage gauges of the key hydrologic network in eastern Cuba and 14 water stage gauges in western Cuba. The observation period is $42-50$ years and short-term records concerning precipitation within the multiyear period.

\footnotetext{
* Corresponding author: pirit35@yandex.ru
} 


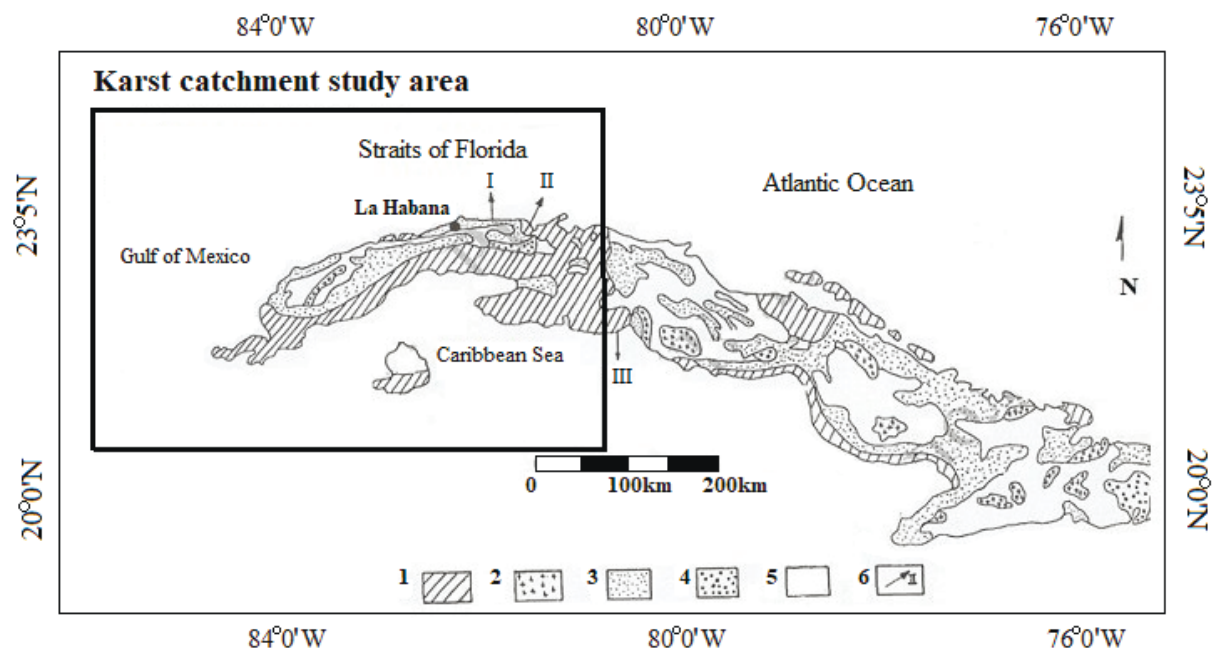

Fig. 1. Karst areas distributions in Cuba (engineering-geological classification [3]): 1 - karst with drainage into underlying strata, 2 - karst with local drainage, 3 - karst with adjacent drainage, 4 non-karstic rocks, 5 - study areas (I - Sants Cruz Thermal Power Plant, II - Matanzas Thermal Power Plant, Juragua Nuclear Power Plant).

The linear-correlation model of water balance $[5,6]$ is used to carry out a qualitative and quantitative analysis of karst influence on river run-off.

\section{Results and discussion}

Among other parameters this model includes $R_{0}$ - depth of absorption in closed depressions after the period of water formation. This will be used later to evaluate the influence of karst on infiltration, run-off and water balance. The method of calculation of depth of absorption $R_{0}$ is described in the work [5] and uses the geomorphologic factor $\Phi$ [7], which is the ratio of slope length of the catchment area 1 to the square root of watershed slope $I_{\text {вод }}$. As the parameter $b$ includes:

$$
b=R_{1}+R_{0}
$$

we have to make the dependence graph $\frac{b}{P}=f(\Phi)$ (Fig. 2) which consists of seven groups of points, with various slopes.

$R_{0}$ can be also easily calculated with the tangent of an angle of the lines on the dependence graph $\frac{b}{P}=f(\Phi)$.

$R_{0}$ is used to make the dependence graph to $\frac{U}{P}=f\left(\frac{R_{0}}{P}\right)$ calculate the degree of karst influence on infiltration capacity. It is presented in Fig. 3.

The graph of the correction factor of infiltration capacity change is presented in Fig. 4. 


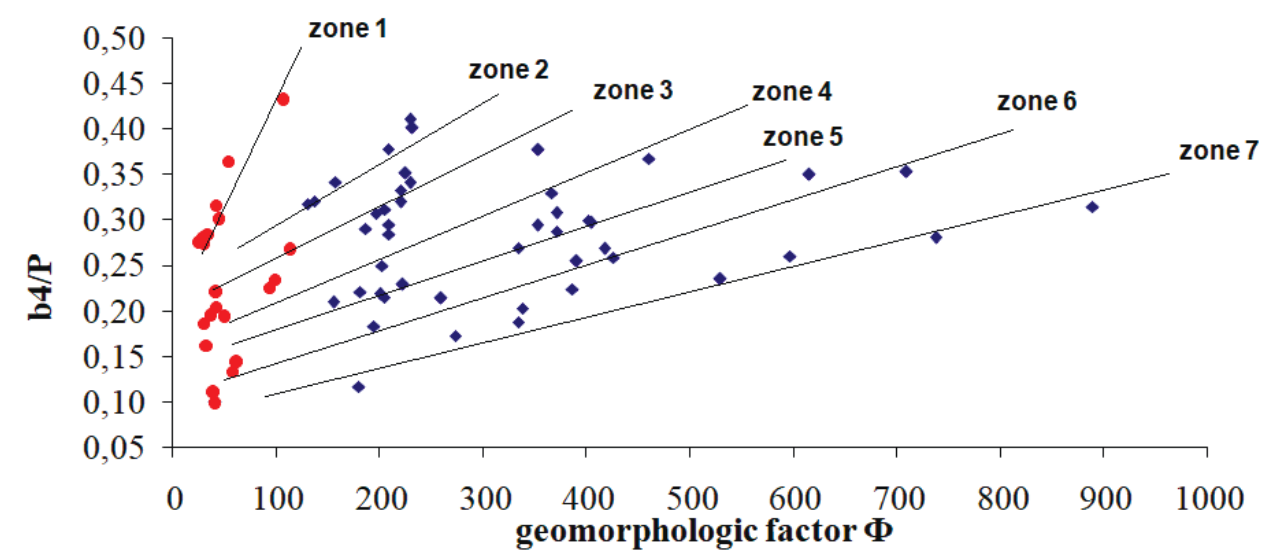

Fig 2. Dependence between relative absorption capacity and ruggedness of terrain.

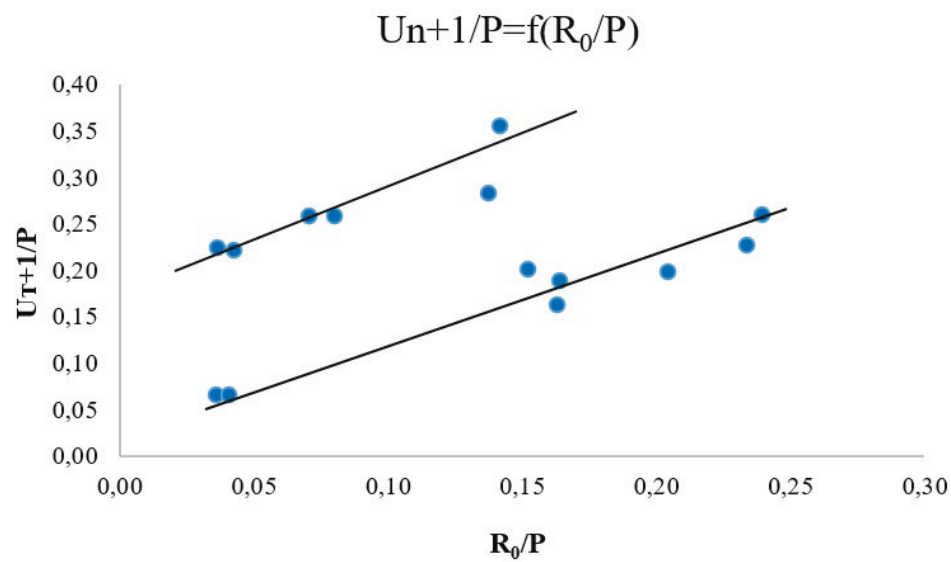

Fig. 3. Dependence between relative infiltration capacity and layer of run-off accumulation in the catchment area.

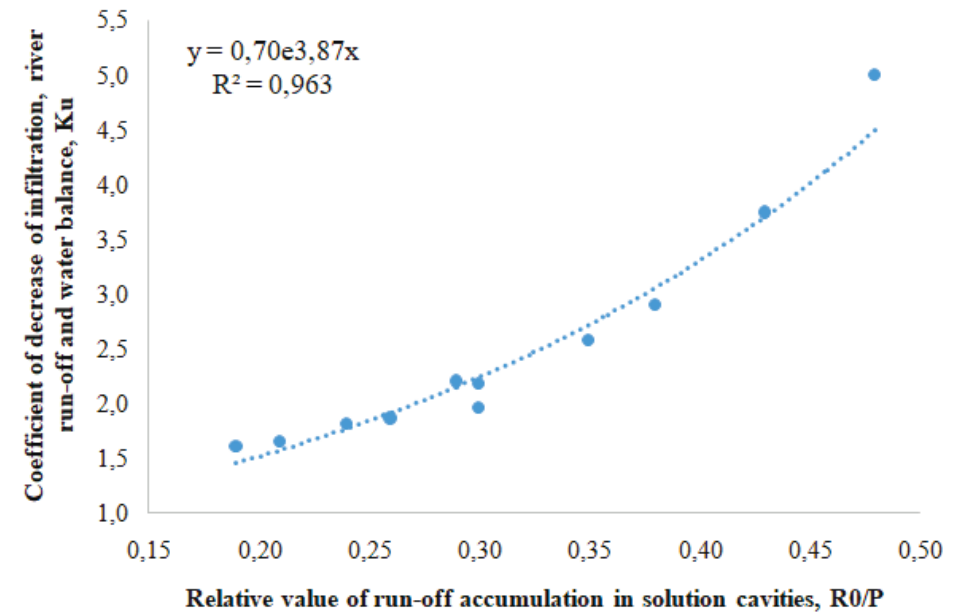

Fig. 4. Dependence for the coefficient of karst influence on infiltration capacity. 
To estimate the scale of this influence it is necessary to study the expression for infiltration capacity from other works $[5,6]$ :

$$
U=\frac{Y(1-k)}{k}
$$

where $\mathrm{Y}$ - depth of streamflow, $\mathrm{mm} ; \mathrm{k}$ - regression coefficient of the correlation dependence between streamflow and precipitation depth.

\section{Conclusion}

The study suggests the method to consider karst influence on infiltration capacity, as well as on river run-off and water balance. The method can prove accurate if additional observation data from adjacent catchment areas with karst is taken into account.

\section{Reference}

1. V.A. Balkov, Karst influence on river run-offs in European part of the USSR, Gidrometeoizdat (1970)

2. G.A. Maksimovich, Basis for karst studies. Geographical Society of the USSR, 2 (1969)

3. E.N. Swaletski, M.A. Iturralde, Estudio ingeniero-geológico del carso cubano. Serie Espeleológica y Carsológica, 31, A. de Ciencias de Cuba (1971)

4. Garcia Miguel Osvaldo, Aseanio Genesis y clasificacion de los suelos Huimico carbonaticos de los principales regiones de Cuba. Resumen de tesis (1984)

5. Z.K. Iofin, Improving the theory of water balance elements formation in river basins, Logos (2012)

6. Z.K. Iofin, Reclamation and Water Management, 5, 11-16 (2015)

7. A.N. Befany, E.N. Melnichuk, Proceedings of Ukrainian Research Institute of Hydrometeorology, 69, 105-137 (1967) 